\title{
The Conjugative Transfer of the Multiresistance Gene Between Bacteria is Significantly Promoted by Nano-Alumina
}

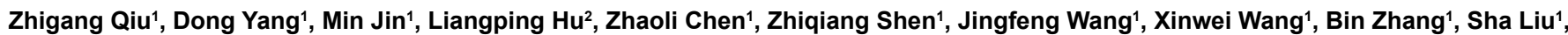 \\ Yunmei $\mathrm{Yu}^{1}$ and Jun-Wen $\mathrm{Li}^{1 \star}$
}

${ }^{1}$ Institute of Health and Environmental Medicine, Key Laboratory of Risk Assessment and Control for Environment \& Food Safety, No.1, Dali Road, Tianjin, 300050, China ${ }^{2}$ Consulting Center of Biomedical Statistics, No. 27, Taiping Road, Beijing, 100850, China

\begin{abstract}
Recently, the potential risks of nanomaterials and the spread of antibiotic resistance have become two important environmental concerns. The conjugative transfer of antibiotic resistance genes between bacteria is the most important pathway for the acquisition of antibiotic resistance by bacteria. Both environmental and genetic factors influence the conjugative transfer of antibiotic resistance genes in bacterial populations. The extent to which nanomaterials are able to bring about an increase in antibiotic resistance by regulating the conjugative transfer of antibiotic resistance genes in bacteria is still unknown. In this paper, an Orthogonal Design $\mathrm{L}_{64}\left(4^{21}\right)$ was used in duplicate to evaluate the effects of bacterial concentration, nano-alumina concentration, mating time, mating temperature and the interactions of those factors on the conjugation transfer in LB broth. The mechanisms by which nano-alumina promote the horizontal transfer of antibiotic multiresistance features were explored by morphological, biochemical, and molecular biological methods. We have shown that nano-alumina promotes the horizontal conjugative transfer multiresistance genes mediated by RP4 up to 250-fold in LB broth and 100-fold in PBS. And it would appear that the effect of promoting conjugative transfer of nano-alumina exceeds the effects of mating temperature and mating time. We also explored the mechanisms behind this phenomenon and demonstrated that nano-alumina is able to induce oxidative stress, cause the damage of bacterial cell membranes, enhance the transcriptional activity of conjugative genes and depress the global regulatory factor genes expression. The findings in this study support the notion that nano-alumina in the environment could result in ecological hazards. More important, an enhanced rate of plasmid transfer among micro-organisms may have an enormous impact on human health and environmental safety.
\end{abstract}

\section{Introduction}

Over the past few decades, microorganisms have developed a greater ability to withstand the effects of antibiotics due to several factors, which include the overuse or misuse of drugs in medicine and agriculture [1]. The development and spread of antimicrobial resistance in bacterial populations is of increasing concern, as it can lead to major difficulties in the treatment of diseases. These are exemplified by the existence of methicillin-resistant Staphylococcus aureus (MRSA) [2], and particularly the appearance of the new "Super Bug" in 2010 and its dissemination in all the world [3,4]. Many antibiotic resistance genes reside on plasmids. These facilitate the transfer of genetic information in a horizontal fashion between individual cells or species by plasmid exchange within their natural environment [5]. Of all the mechanisms and mobile elements that mediate horizontal gene transfer between bacteria, conjugation by self-transferable plasmids may be the most important [6]. The critical role that plasmids play in the rapid spread of antibiotic resistance genes is particularly salient [7].

Experimental data has shown that a number of environmental factors, including exposure to antimicrobial agents [8], as well as nutrient and water availability, can influence this horizontal plasmid transfer [9].

Nanomaterials, which often possess novel physical, chemical, and biological properties, are being utilised in an increasing number of fields. The use of nanoparticles (NPs) in commercial products and industrial applications has increased greatly in recent years, although understanding of the interaction mechanisms at the molecular level between NPs and biological systems is largely lacking [10]. In some of those products, such as skin creams and toothpastes, NPs can enter the water environment on a continual basis from the removal of such products, such as by hand-washing [11]. Even worse, a fatal accident during the production of engineered nanomaterials could release a significant quantity of NPs into the water environment [12]. At the same time, scientists have also found ways of using nanomaterials in environmental remediation. Many of these are still in the testing phase [13-15]. One example is nano-alumina, which can adsorb and oxidise contaminants. Nano-alumina is already used to minimise the concentrations of contaminants in water and waste water, and to remove humic-acids from water and to improve sludge conditioning [16-19]. Their use in water treatment may result in a considerable amount of nanomaterial residue in the water [20,21]. Otherwise, nanosized materials at the same time they may, in fact, become new environmental hazards themselves.

The potential hazards associated with nanomaterials in the environment have resulted in heightened awareness and concern for their impact on health worldwide [12,22,23]. Moreover, some studies have indicated that nanomaterials can cause disruption to bacterial membranes or substantial damage to DNA, probably by the production of reactive oxygen species (ROS) [24,25] and can deliver DNA or RNA molecules into animal or plant cells $[26,27]$. Based on the above, we hypothesised that nanomaterials that are present in water

*Corresponding author: Jun-Wen Li, Department of Environment and Health, Institute of Health and Environmental Medicine, No.1, Dali Road, Tianjin, 300050, China, Tel: 86-22-84655345; Fax: 86-22-23328809; E-mail: junwen9999@hotmail.com

Received August 01, 2012; Accepted November 28, 2012; Published December 01,2012

Citation: Qiu Z, Yang D, Jin M, Hu L, Chen Z, et al. (2012) The Conjugative Transfer of the Multiresistance Gene Between Bacteria is Significantly Promoted by Nano-Alumina. J Nanomed Nanotechol 3:154. doi:10.4172/2157-7439.1000154

Copyright: (c) 2012 Qu Z, et al. This is an open-access article distributed unde the terms of the Creative Commons Attribution License, which permits unrestricted use, distribution, and reproduction in any medium, provided the original author and source are credited. 
may promote the horizontal transfer of multidrug-resistance genes between bacteria by acting on cell membranes and/or regulating genes involved in plasmid transfer.

In this study, we described the effect of nano-alumina on the horizontal transfer of antibiotic multiresistance genes mediated by RP4 between Escherichia coli. We analysed the effect of bacteria concentration, concentration of nano-alumina, mating time, and mating temperature on conjugation using orthogonal design which are fractioned factorial designs that allow testing multiple independent processes variables within a single experiment and were used by many scholars [28-31]. We also explored the mechanisms by which nanoalumina promote the horizontal transfer of antibiotic multiresistance features by morphological, biochemical, and molecular biological methods. These studies were the first to identify that the presence of nano-alumina in water resulted in a very significant increase in interspecies conjugation of the mobilisable shuttle plasmid RP4.

\section{Experimental Section}

\section{Bacteria conjugation experiment based on orthogonal exper- imental design}

An Orthogonal Design $\mathrm{L}_{64}\left(4^{21}\right)$ was used in duplicate to evaluate the effects of bacterial concentration, nano-alumina concentration, mating time, mating temperature and the interactions of those factors on the conjugation transfer in LB broth. As our results of preliminary experiments showed that the $\mathrm{pH}$ value of common water environment had no significant effect on conjugal transfer, the $\mathrm{pH}$ value was not adopted in the orthogonal experiment. The levels of the bacteria concentration were $10^{5}, 10^{6}, 10^{7}$ and $10^{8} \mathrm{CFU} / \mathrm{mL}$. The levels of nanoalumina concentration were $0,0.5,5$ and $50 \mathrm{mmol} / \mathrm{L}$. The levels of the mating time were $2,4,6$ and $8 \mathrm{~h}$, and the levels of the mating temperature were $4,15,25$ and $37^{\circ} \mathrm{C}$. The orthogonal experiment scheme is shown in Supplementary Table 1.

The E. coli strain HB101 [32], which contains the RP4 plasmid carring kanamycin resistance, served as donor bacteria for conjugation. E. coli K12 (ATCC 47076) acquired a nalidixic acid-resistant mutant, $\mathrm{K} 12 \mathrm{Nal}[33,34]$, which was used as the recipient strain. Strains were grown at $37^{\circ} \mathrm{C}$ in $\mathrm{LB}$ broth with appropriate antibiotics, as follows: kanamycin (Km, product number K1377-25G [Sigma-Aldrich, 3050 Spruce St. St. Louis, MO 63103, USA]), $60 \mathrm{mg} / \mathrm{L}$ for donor E. coli HB101 bearing RP4 plasmid), and nalidixic acid (Nal, product number N8878-25G, Sigma-Aldrich) $100 \mathrm{~g} / \mathrm{L}$ was used for the E. coli K12.

Sixty-four sterile glass tubes (Diameter: $18 \mathrm{~mm}$, and Length: $180 \mathrm{~mm}$ ) were marked with a number from 1 to 64 , respectively. Each number corresponded to an experimental condition for one group in the orthogonal experiment. For each experiment, donor and recipient strains were grown separately over night at $37^{\circ} \mathrm{C}$ in LB with the appropriate antibiotics. Equal amounts of donor and recipient cells were then mixed. To prepare this initial 50:50 cell mixture, the optical densities (OD600) of the overnight cultures were measured and appropriate culture volumes were taken to ensure the cells concentration fit the experimental conditions. The bacteria cells were centrifuged for $1 \mathrm{~min}$ at $10,000 \mathrm{~g}$ at room temperature, and the resulting pellets were re-suspended in $1 \mathrm{ml}$ of saline solution $(\mathrm{NaCl}$, $8.5 \mathrm{~g} / \mathrm{L}$ ) and re-centrifuged. The new pellets were re-suspended in LB in a volume determined by the average of the initial culture volumes and then mixed together. Then, $9.5 \mathrm{ml}$ of the suspension was aliquoted into sterile glass tubes marked with the number that corresponded to the experimental condition. Then, $0.5 \mathrm{~mL}$ dispersions of nano-alumina (product number 642991, $100 \mathrm{~mL}$, Sigma-Aldrich, particle size is $<50$ $\mathrm{nm}$ (TEM), diluted with sterile water to a concentration corresponded to the experimental condition) or sterile water was aliquoted into the glass tubes. The culture was vigorously mixed by vortexing.

After all the 64 group experiments were prepared, the cultures were incubated in different temperature incubators and different times, according to the experimental design. The specified cultures were vigorously mixed and appropriate dilutions were spread on LB selection plates (containing $60 \mathrm{mg} / \mathrm{L} \mathrm{Km}$ and $100 \mathrm{mg} / \mathrm{L} \mathrm{Nal}$ ). After overnight incubation of the plates at $37^{\circ} \mathrm{C}$, the colonies were counted and the results were presented as colony forming units per milliliter culture $(\mathrm{CFU} / \mathrm{mL})$.

In parallel, the HB101 and K12 bacteria were also plated onto LB selection plates (containing $60 \mathrm{mg} \mathrm{Km}$ and $100 \mathrm{mg} \mathrm{Nal}$ ) to ensure that the bacteria growing on the double-antibiotic agar medium were transconjugants to rule out the spontaneous mutation of HB101 and K12. A further control group was established using bulk alumina (product number H7881-10G, particle size is mean $5 \mu \mathrm{m}$ SigmaAldrich) in order to confirm the effects of the nano-structure of alumina on the conjugative transfer of RP4. Finally, HB101 bacteria bearing a non-conjugative plasmid pCB182 [35] was used as the donor bacteria to observe the transformation of free plasmids dissolved from died bacteria in the presence of nano-alumina.

A further orthogonal experimental was carried out to evaluate the effects of bacterial concentration, nano-alumina concentration, mating time, mating temperature and the interactions of those factors on the conjugation transfer in Phosphate Buffered Saline (PBS, Ingredients: $\mathrm{NaCl} 137 \mathrm{mmol} / \mathrm{L}, \mathrm{KCl} 2.7 \mathrm{mmol} / \mathrm{L}, \mathrm{Na}_{2} \mathrm{HPO}_{4} 10 \mathrm{mmol} / \mathrm{L}$, $\mathrm{KH}_{2} \mathrm{PO}_{4} 2 \mathrm{mmol} / \mathrm{L}$, pH7.4). The experimental design and experimental procedures were the same as the experiment carried out in LB broth, but the media was changed to PBS. All of the above-described control groups were also carried out in parallel.

All the strains and plasmid used in this study are shown in Supplementary Table 2 .

\section{Samples preparation for TEM, anti-oxidant systems detection, transcriptional activity detection and real-time PCR}

To prepare samples for further experiments, the bacteria mating experiments based on Factorial Design with two factors was performed. The protocols were as follows: all the strains were incubated and treated as described in the "Bacteria conjugation experiment based on orthogonal experimental design" section. The cell density was adjusted to an optical density at $600 \mathrm{~nm}$ (OD600) of 0.1 , and then donor and recipients were mixed 50:50 in LB medium. In the same time, a specified concentration and volume dispersions of nano-alumina or bulk alumina were aliquoted into the LB medium, and the final concentrations of alumina were $0,0.05,0.5,5$ and $50 \mathrm{mmol} / \mathrm{L}$. After incubated at $37^{\circ} \mathrm{C}$ for $8 \mathrm{~h}$, the mating mixtures were centrifuged at $1,000 \mathrm{~g}$ for $20 \mathrm{~min}$ at $4^{\circ} \mathrm{C}$. Then, the supernatant of each sample was completely removed, and the cell pellet was used for further experiments. In order to prepare samples for the detection of transcriptional activity, the donor strains used in the conjugation experiments were HB101 (RP4+PCB267.1) and HB101 (RP4+PCB267.2).

The cell pellet was re-suspended gently with the pre-cooled $2.5 \%$ glutaraldehyde fixative. Then the samples were fixed at $4^{\circ} \mathrm{C}$ for 2 hours. Next, the liquid was centrifuged at $1,000 \mathrm{~g}$ for $20 \mathrm{~min}$, after which the clarified supernatant was removed. The cell pellet was washed twice with 
$0.2 \mathrm{~mol} / \mathrm{L}$ citric acid solution and then centrifuged again. The samples were then fixed with $2 \% \mathrm{OsO}_{4}$ in anhydrous acetone that contained $8 \%$ dimethoxypropane for two days at $4^{\circ} \mathrm{C}$, followed by dehydration using gradient ethanol method. Afterwards, the precipitate was treated with propylene oxide, and then embedded in Epon 812 resin. The samples were sectioned into slices about $50 \mathrm{~nm}$ with ultra microtome (LEICA ULTRACUT-R). Following post-staining with $2 \%$ aqueous uranyl acetate for $15 \mathrm{~min}$ and Reynold's lead citrate for $5 \mathrm{~min}$, the samples were examined and photographed with a HITACHI-7500 transmission electron microscope and Megaview digitalisation electron microscope photograph system. The elements in the bacterial slice were analysed by high-resolution TEM (Philips TECNAI G2F20) with energy dispersive analysis system of X-ray (GENESIS).

\section{Detection of bacterial anti-oxidant systems}

The cell precipitation which contained both donor and recipient was washed with PBS twice. Then cell precipitation was re-suspended with $1 \mathrm{~mL}$ PBS. The cell suspension was broken into pieces with ultrasonic cracker (JY92-IIN). The suspension was centrifuged at 10,000 $\mathrm{g}$ for 10 $\min$ at $4^{\circ} \mathrm{C}$. Then, the protein fraction of the supernatant was quantified with a protein quantification kit (SK3051, Shanghai Sangon Biological Engineering Technology \& Services Co., Ltd.), and the levels of $\mathrm{OH} \bullet$, T-AOC, SOD, CAT and GR were analysed. The activity levels of these enzymes were tested with appropriate kits from the Nanjing Jiancheng Bioengineering Institute (Nanjing, China).

\section{Construction of transcriptional fusions and detection of transcriptional activity}

The trbBp and trfAp regions of RP4 plasmid were amplified by PCR using primers that contained BglII restriction sites (Supplementary Table 3), upon which BglII (Takara, Kyoto, Japan) was added. The primers and reaction conditions for the amplification of $\operatorname{tr} b B p$ and $\operatorname{trfA} p$ were according to a previous study) [36].

These two PCR products were cloned into the pTZ57R/T vector (Fermentas, USA). After verifying the correct promoter regions through PCR amplification and sequence analysis, these plasmids were called pTZ57R.1 (containing trbBp) and pTZ57R.2 (containing trfAp), respectively.

The method of cloning trbBp and trfAp into pCB267 [37] vector was as follows. The pTZ57R.1 and pTZ57R.2 were cultured overnight in LB culture medium that contained $50 \mathrm{mg} / \mathrm{L}$ ampicillin (Amp). The plasmids were then extracted, purified, and restricted at $37^{\circ} \mathrm{C}$ for 1 hour with $B g l I I$. Subsequently, $5 \mu \mathrm{L}$ of the target gene sequence and plasmid vector that were acquired after restriction and purification were ligated overnight. As a consequence, we were able to obtain pCB267.1 (containing trbBp) and pCB267.2 (containing trfAp). Samples that contained $5 \mu \mathrm{L}$ aliquots of purified pCB267.1 or pCB267.2 were transformed into competent E. coli HB101 (RP4), shaken for 1 hour at $37^{\circ} \mathrm{C}$, transferred onto LB plates with $60 \mathrm{mg} / \mathrm{L} \mathrm{Km}$ and $50 \mathrm{mg} / \mathrm{L} \mathrm{Amp}$, and then cultured overnight at $37^{\circ} \mathrm{C}$. Red colonies which pCB267.1 or pCB267.2 were transformed successfully were selected and cultured in LB medium that contained $60 \mathrm{mg} / \mathrm{L} \mathrm{Km}$ and $50 \mathrm{mg} / \mathrm{L}$ Amp. Positive clones were identified by amplification through PCR of the trbBp and trfAp genes from the plasmids. The two strains containing two plasmid called HB101 (RP4+PCB267.1) and HB101 (RP4+PCB267.2).

The cell pellets were used to detect the transcriptional activities of trbBp and $\operatorname{trfA} p$ with a kit (GMS60003.3 V.A GENMED SCIENTIFICS INC. U.S.A).

\section{Detection of mRNA expression of global regulatory genes}

The total bacterial RNA was extracted from the cell pellet with a RNA extraction kit (Invitrogen, USA). Subsequently, the RNA was reverse-transcribed into DNA by RT-PCR with a reverse transcription kit (Invitrogen, USA). Real-time PCR was carried out using SYBR Green I (TaKaRa, Japan), and the absolute quantification method was used to quantify the global regulatory genes: $\operatorname{Kor} A, \operatorname{Kor} B$ and $\operatorname{trb} A$ of RP4. The 16s rRNA was used as the internal control. The primers were designed specifically for this study using Oligo 6.0, and primer sequences are listed in Supplementary Table 4. Regulatory gene primers and 16s rRNA primers were synthesised by Invitrogen. The reaction conditions used for the two-step PCR procedure are as follows: an initial denaturation at $95^{\circ} \mathrm{C}$ for $30 \mathrm{sec}$, a PCR step of 40 cycles of $95^{\circ} \mathrm{C}$ for $5 \mathrm{~s}$ and $60^{\circ} \mathrm{C}$ for $31 \mathrm{~s}$, and a dissociation stage of $95^{\circ} \mathrm{C}$ for $15 \mathrm{~s}$, $60^{\circ} \mathrm{C}$ for $1 \mathrm{~min}$, and $95^{\circ} \mathrm{C}$ for $15 \mathrm{~s}$. The real-time PCR equipment was Applied Biosystems 7300 Real-Time PCR System, and the software was SDS v1.3.2.

\section{Statistical analyses}

All data were analysed using SAS 9.2 software version for windows (SAS (r) Proprietary Software 9.2 (TS2M2), Licensed to Academy of Military Medical Sciences, Site 11201240).The bacterial conjugation experimental results were analysed by the "analysis of variance of univariate quantitative data of the orthogonal design" method. All of the mechanistic experiments were conducted using Factorial Design with two factors for at least three separate experiments in duplicate, and the results were analysed by the "analysis of variance of univariate quantitative data of the two-factor factorial design" method. P-values less than 0.05 were considered statistically significant.

\section{Results}

\section{Effects of nano-alumina on the conjugative transfer of the RP4 plasmid}

In order to ensure the accuracy of the experiment, we carried out two batches orthogonal test in Luria-Bertani (LB) broth to determine the effects of the bacterial concentration, the nano-alumina concentrations, mating time and mating temperature on the formation of transconjugations. The results are shown in Figure 1. The statistically analysed results are shown in the Supplementary SAS Output. The statistical results shown that, every one of these four factors has a significant effect on the formation of transconjugations, while there

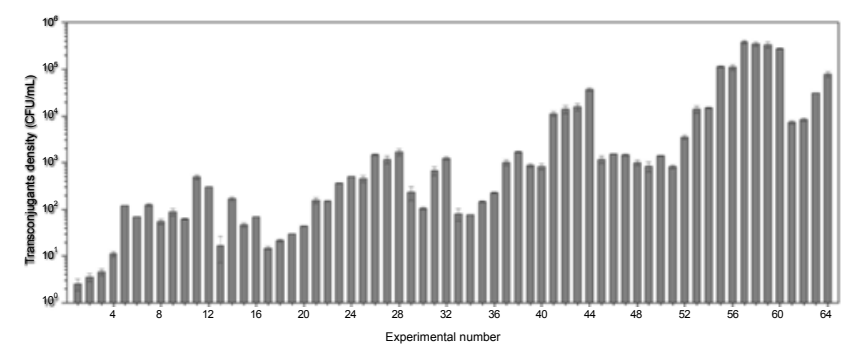

Figure 1: The results of the Orthogonal Design Experiments $L_{64}\left(4^{21}\right)$ in LB broth. The results of conjugation obtained with the non-conjugative plasmid pCB182 were zero. This revealed that the uptake of naked DNA does not occur by transformation. Furthermore, the results of conjugations induced by bulk alumina were almost the same as the results when the nano-alumina concentrations were $0 \mathrm{mmol} / \mathrm{L}$. 
Citation: Qiu Z, Yang D, Jin M, Hu L, Chen Z, et al. (2012) The Conjugative Transfer of the Multiresistance Gene Between Bacteria is Significantly Promoted by Nano-Alumina. J Nanomed Nanotechol 3:154. doi:10.4172/2157-7439.1000154

was an interaction effect between the bacteria concentration and nanoalumina concentration.

The ranking of these factors in the order of importance of affecting the formation of transconjugations was as follows: bacteria concentration $>$ nano-alumina concentration $>$ mating time $>$ mating temperature $>$ the interaction between bacterial concentration and the nano-alumina concentration.

After further analyses of the effects of different levels of each factor on the formation of transconjugations, we found that the number of transconjugants increased with increasing bacterial concentration, mating time and mating temperature. The mating time could be divided into two sub-groups: $2-4 \mathrm{~h}$, and 6-8 $\mathrm{h}$. There was no significant difference between the two time periods in all sub-groups, but there was a significant difference between the two groups. The levels of mating temperatures could be divided into three sub-groups. There was no significant difference in terms of the influence of temperature on the formation of transconjugations between $15^{\circ} \mathrm{C}$ and $25^{\circ} \mathrm{C}$. However, it was very significantly higher $(\mathrm{P}<0.05)$ than that at $4^{\circ} \mathrm{C}$ and significantly lower than that at $37^{\circ} \mathrm{C}$.

We focused more on the effect of nano-alumina on the formation of transconjugations. Our results showed that the effects of different levels of nano-alumina on the formation of transconjugations were not identical with the other three factors. With increasing concentrations of nano-alumina, the number of tranconjugants was significantly elevated; at $5 \mathrm{mmol} / \mathrm{L}$, the number of tranconjugants peaked and was 2.4 orders of magnitude ( 250 -fold) higher than no nano-alumina or bulk alumina treatment. When the nano-alumina concentration was $50 \mathrm{mmol} / \mathrm{L}$, the number of transconjugants was lower than that at 5 $\mathrm{mmol} / \mathrm{L}$.

We also investigated the effect of nano-alumina on the formation of transconjugants in PBS instead of LB broth in order to simulate the RP4 transfer process in the natural water environments without nutrition. The results were consistent with those observed in LB broth. When the nano-alumina concentration was $5 \mathrm{mmol} / \mathrm{L}$, the highest number of transconjugants were noted, which were increased by more 100 times than those in the control groups (Supplementary Figure 1).

The above results indicate that nano-alumina can significantly promote the formation of transconjugants of RP4, while bulk alumina had no effect on the formation of transconjugants of RP4. The ability of nano-alumina to promote conjugative transfer far exceeded the effects of mating temperature and mating time.

\section{The effect of nano-alumina on cell membranes and its distribution in cells}

We observed the morphology of the parent bacteria using transmission electron microscopy (TEM), and the results indicate that the cell membranes in the control group $(0 \mathrm{mmol} / \mathrm{L})$ and the groups with different concentrations of bulk alumina were intact with cell borders that were clearly visible. The cytoplasm was compact and distributed evenly (Figures $2 \mathrm{a}, \mathrm{b}$ and $\mathrm{c}$ ). When observing the bacteria in the 5 $\mathrm{mmol} / \mathrm{L}$ nano-alumina treatment group, we found that the cytoplasm of the bacteria was agglomerated and that parts of the cell membranes were undefined (Figure $2 \mathrm{~d}$ ). When the concentration of nano-alumina was increased to $50 \mathrm{mmol} / \mathrm{L}$, portions of the cell membranes of the parent bacteria were severely damaged, and the borders of the cell membranes were also unclear (Figure 2e). Furthermore, a number of spherical, highly dense particles were observed in these bacterial cells (Figures 2d). Subsequently, we used energy dispersive analysis (EDS) technology to analyse the elements that were present in the regions around the highly dense particles in the ultra-thin bacterial slices (Figure 2f). The EDS results showed that there were high levels of aluminium in this region. It indicates that the nano-alumina not only damaged the structure of the cell membrane of bacteria, but also entered into bacterial cells.

\section{The effects of nano-alumina on bacteria conjugation}

Conjugation resulted in the formation of a compact electron-dense area between the outer cell membranes of the donor and recipient, as visualised by TEM and the outer cell membranes of the two cells appeared to be fused [32]. We selected 6 to 10 visual fields at random in a single sample; fields were magnified by 20,000 times to observe the conjugants. We found that there were few junctions observed in the control group $(0 \mathrm{mmol} / \mathrm{L})$ and bulk alumina groups (Figure $3 \mathrm{a}, \mathrm{b}, \mathrm{c}$, d), but conjugants occurred between numerous bacteria in the nano-
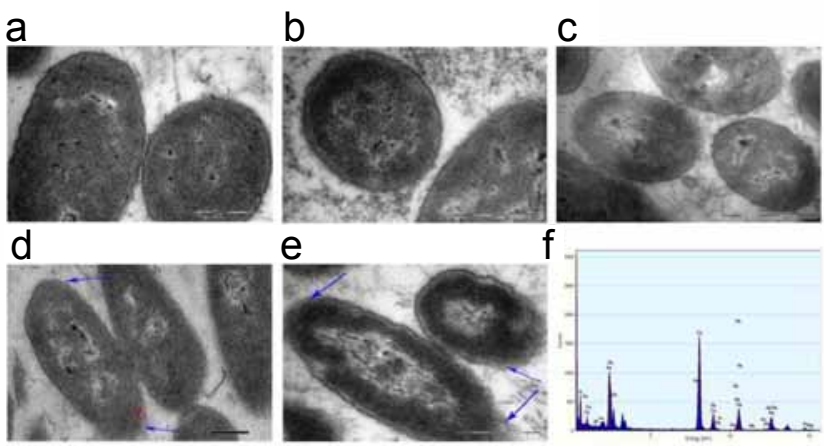

Figure 2: Detection of $E$. coli in ultrafine slices by TEM and elements analysis. $a-c)$ In the control group (a, $0 \mathrm{mmol} / \mathrm{L})$ and bulk alumina groups (b, $5 \mathrm{mmol} / \mathrm{L} ; \mathrm{c}, 50 \mathrm{mmol} / \mathrm{L}$ ), the cell membranes are distinct, and the cytoplasm is compact; $d$ and e) the cell membranes of bacteria, which were treated with different concentrations of nano-alumina (d, $5 \mathrm{mmol} / \mathrm{L}$; e, $50 \mathrm{mmol} / \mathrm{L})$ were damaged (indicated with blue arrows), and the extent of damage increased with increasing concentrations of nano-alumina. There were also many highly dense particles in cells (red astragal zone); f) the composition of chemical elements in the bacterial red astragal zone. Scale bars: $500 \mathrm{~nm}$.

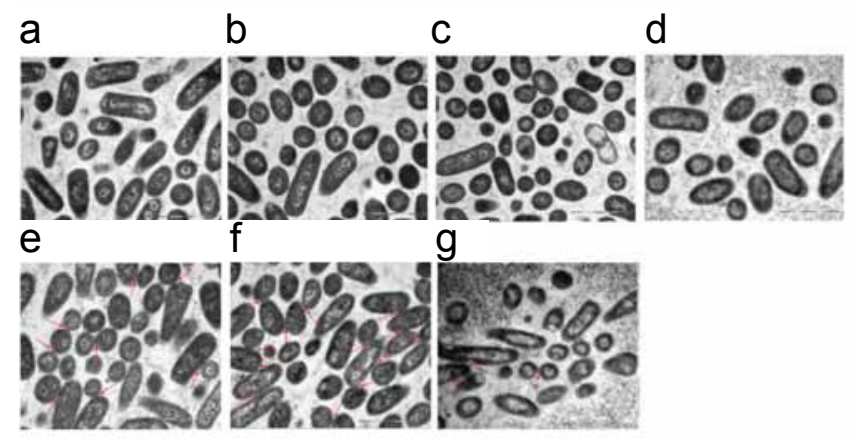

Figure 3: TEM micrographs of the conjugative junctions of mating cells. a-d) The conjugative junctions of mating cells in the control $(\mathrm{a}, 0 \mathrm{mmol} / \mathrm{L})$ and bulk alumina groups (b: $0.5 \mathrm{mmol} / \mathrm{L}$, c: $5 \mathrm{mmol} / \mathrm{L}$, d: $50 \mathrm{mmol} / \mathrm{L}$ ). No conjugation was found; e-g) the conjugative junctions of mating cells in the nano-alumina groups (e, $0.5 \mathrm{mmol} / \mathrm{L} ; \mathrm{f}, 5.0 \mathrm{mmol} / \mathrm{L} ; \mathrm{g}, 50.0 \mathrm{mmol} / \mathrm{L})$. The red arrows indicate that conjugations occurred between two bacteria or multiple bacteria. The numbers of conjugations of nano-alumina groups were much greater in these groups than in the controls and the bulk alumina groups, and the $5 \mathrm{mmol} / \mathrm{L}$ nano-alumina group had the greatest number of conjugations. Scale bars: $2 \mu \mathrm{m}$. 
alumina groups (Figure $3 \mathrm{e}, \mathrm{f}, \mathrm{g}$ ), and a single bacterium might even be conjugated with multiple other bacteria in a single view. The number of the junctions in the $5 \mathrm{mmol} / \mathrm{L}$ nano-alumina groups was the highest in all of the nano-alumina groups. Moreover, the aggregation of nanoparticles was observed to some extent in the $50 \mathrm{mmol} / \mathrm{L}$ nano-alumina groups.

We used the fused promoter to detect the transcriptional activity of the RP4 conjugation genes, $\operatorname{tr} b B p$ and $\operatorname{trfAp}$, which regulated the formation of conjugation bridges and regulated RP4 processing into a single chain, transferring from the donor to recipients and replicating from single chain to double chains in recipient, respectively. Results indicated that $\beta$-glycosidase activities from these two reporters were relatively low in the control group $(0 \mathrm{mmol} / \mathrm{L})$ and the bulk alumina groups (Figure 4), and there were no significant differences between those groups. In contrast, the activities were significantly higher in all the nano-alumina groups compared to the control group and the bulk alumina groups. With increasing the concentration of nanoalumina, the transcriptional activities of both $\operatorname{tr} b B p$ and $\operatorname{trf} A p$ increased significantly. Our results indicate that high concentrations of nanoalumina can enhance the transcriptional activities of the trbBp and trfAp of RP4 conjugation genes to make more conjugants forming.

\section{The effect of nano-alumina on bacterial oxidative stress- response systems}

We assessed whether nano-alumina affects the bacterial oxidative stress-response systems under these conditions. We found that the levels of hydroxyl free radicals $(\mathrm{OH} \bullet)$ were significantly higher at all of the nano-alumina concentrations than those in the control group and bulk alumina groups. The $\mathrm{OH} \bullet$ yield of the bacteria treated with nanoalumina increased in a manner that was positively correlated with increasing nano-alumina concentrations (Figure 5a). Simultaneously, there was a significant increase in the total anti-oxidative capacity (T-AOC), as well as the catalase (CAT) superoxide dismutase (SOD) and glutathione reductase (GR) activities of the bacteria at all of the nano-alumina concentrations compared to the control and bulk alumina groups (Figure 5b, c, d, e). Furthermore, with increasing concentrations of nano-alumina, almost all of the levels of oxidative stress were significantly increased. Comparatively, all of the levels of oxidative stress indicators did not differ significantly between the bulk alumina groups and the control group. The results indicate that nanoalumina can affect the oxidative stress-response systems of bacteria in contrast to bulk alumina.

\section{Effects of nano-alumina on the global regulation of RP4 gene expression}

We conducted real-time PCR to estimate the mRNA expression of the major global regulatory genes $\operatorname{kor} A, \operatorname{kor} B$, and $\operatorname{trb} A$ of the RP4 plasmid under the different concentrations of nano-alumina and bulk alumina. The results did not show any significant difference between the mRNA expression of the three genes in the control group and the bulk alumina groups (Figure 6). However, nano-alumina induced a statistically significant repression in mRNA expression at all nanoalumina concentrations compared to the results of the control and bulk alumina groups. With increasing concentrations of nano-alumina, the mRNA expression of kor $A$, $\operatorname{kor} B$ and $\operatorname{trb} A$ decreased significantly. These results show that nano-alumina can significantly repress the expression of the global regulatory genes of the RP4 plasmid, korA, korB and trbA.

\section{Discussion}

Conjugation is one of several mechanisms of horizontal gene transfer by plasmids, which code for traits such as antimicrobial resistance and can be transferred between bacteria. RP4 is a typical IncP $\alpha$-type plasmid, with multidrug-resistant properties that can be transferred by conjugation to other bacteria in either the solid or liquid phase $[38,39]$. The conjugal transfer of RP4 is influenced by many factors, such as cell number density, mating time, and mating temperature, amongst others. Our studies show that a new type environmental pollutant, nano-alumina, participates in the conjugation
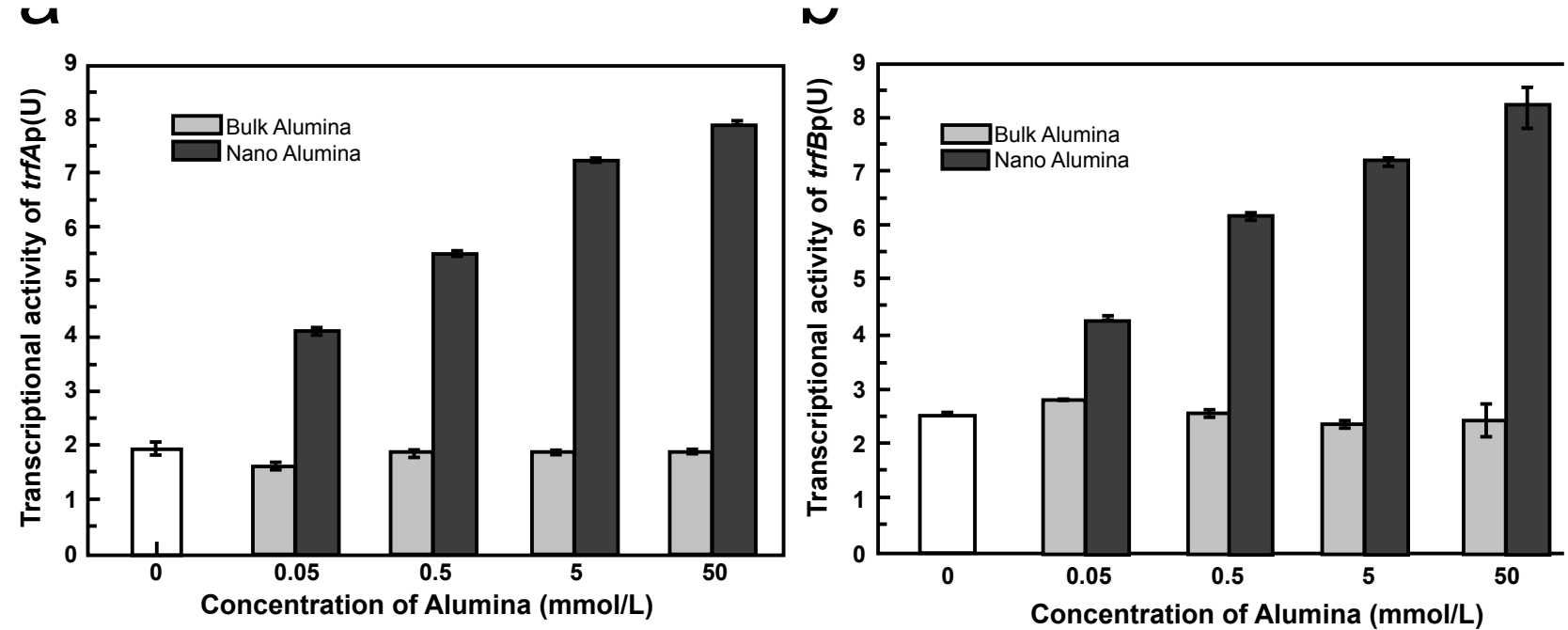

Figure 4: The transcriptional activities of trfAp and trbBp. The transcriptional activities of trfAp (a) and trbBp (b) between the bulk alumina and nano-alumina groups were significantly different between each other (trfAp: $\mathrm{F}=51018.1, \mathrm{P}<0.0001 ; \operatorname{trbBp}: \mathrm{F}=288422, \mathrm{P}<0.0001)$, and at different levels $($ trfAp: $\mathrm{F}=4931.41, \mathrm{P}$ $<0.0001$; trbBp: $F=28606.1, P<0.0001)$. When the process of conjugation was induced by bulk alumina, the transcriptional activities of trfAp and trbBp between the different levels were not significantly different, according to pairwise comparisons $(P>0.05)$. When the conjugal process were induced by nano-alumina, the transcriptional activities of trfAp and trbBp between pairwise comparisons of the different levels were statistically significant different $(\mathrm{P}<0.01)$. 
Citation: Qiu Z, Yang D, Jin M, Hu L, Chen Z, et al. (2012) The Conjugative Transfer of the Multiresistance Gene Between Bacteria is Significantly Promoted by Nano-Alumina. J Nanomed Nanotechol 3:154. doi:10.4172/2157-7439.1000154
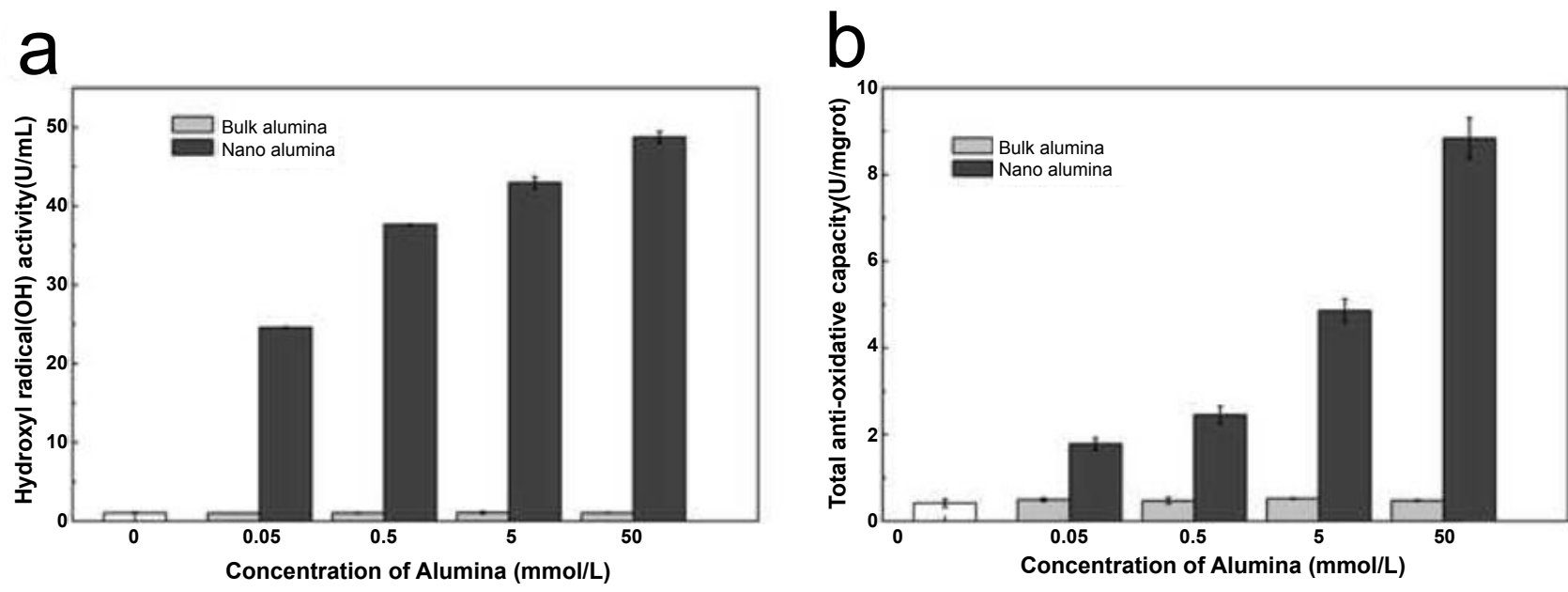

C

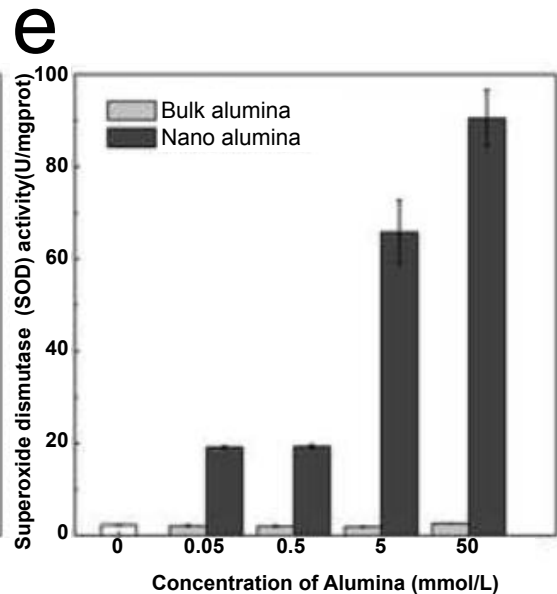

Figure 5: The effect of nano-alumina on the bacterial anti-oxidant systems. The effects on the activity of OH• (a), T-AOC (b), CAT (c), GR (d) and SOD (e) by either bulk alumina or nano-alumina were significantly different $(\mathrm{OH} \bullet: \mathrm{F}=4728.1, \mathrm{P}<0.0001$; T-AOC: $\mathrm{F}=10,746.0, \mathrm{P}<0.0001 ; \mathrm{CAT}$ : $\mathrm{F}=547.67, \mathrm{P}<0.0001$; $\mathrm{GR}$ : $F=683.77, P<0.0001 ;$ SOD: $F=197,352, P<0.0001)$, and significant differences were also found between different concentrations $(O H \cdot: F=2373.1, P<0.0001$; T-AOC: $F=2,328.37, P<0.0001$; CAT: $F=137.24, P<0.0001$; $G R: F=276.05, P<0.0001$; $S O D$ : $F=39,148.4, P<0.0001$ ). According to a pairwise comparison of the different concentrations, no significant difference was found in the activities of the five anti-oxidant systems indicators when conjugation was induced by bulk alumina ( $\mathrm{P}>0.05$ ), but nano-alumina caused a significant difference in the activities of the five anti-oxidant system indicators $(\mathrm{OH} \bullet: \mathrm{P}<0.05 ; \mathrm{T}-\mathrm{AOC}: \mathrm{P}<0.01 ; \mathrm{CAT}$ : $\mathrm{P}<0.05$ except for 0.05 and $0.5 \mathrm{mmol} / \mathrm{L}[\mathrm{t}=-1.39468, \mathrm{P}=0.1784$ ]; $\mathrm{GR}: \mathrm{P}<0.01$, except for 0 and $0.05 \mathrm{mmol} / \mathrm{L}[\mathrm{t}=-0.43648, P=0.6672], 0.05$ and $0.5 \mathrm{mmol} / \mathrm{L}$ [ $\mathrm{t}=-2.04608$, $\mathrm{P}=0.0541]$; SOD: $\mathrm{P}<0.05$, except for 0.05 and $0.5 \mathrm{mmol} / \mathrm{L}[\mathrm{t}=0.11213, \mathrm{P}=0.9118]$ ).

process of multidrug-resistance plasmids. This has been shown to be the most important factors that influence RP4 conjugal transfer, with the exception of bacterial concentration.

The presence of nano-alumina could promote the transfer of RP4 significantly. The conjugations of drug-resistant plasmids increased with increasing concentrations of nano-alumina and reached a peak at $5 \mathrm{mmol} / \mathrm{L}$ nano-alumina, at which point the number of conjugations increased by an order of magnitude of almost 2.4 (more than 250 times) in LB broth and 100 times in PBS compared to the bacteria in 0 $\mathrm{mmol} / \mathrm{L}$ nano-alumina. When the concentration of nano-alumina was higher than $5 \mathrm{mmol} / \mathrm{L}$, the number of transconjugants decreased, but the number of transconjugants still far exceeded those in the control group. The reason why this promoting effect decreased may be that the particles became aggregated, as showed in the TEM photograph. Therefore, the nano-alumina particles would become relatively less bioavailable than in dispersion at lower concentrations, which is a common phenomenon in all kinds of nano-particles [40]. Alternatively, higher concentrations of nano-alumina (e.g., $50 \mathrm{mmol} / \mathrm{L}$ ) could damage the membrane severely, as was seen from the results of TEM, and inhibited the growth of bacteria (Supplementary Figure 2) in LB broth or kill the majority of bacteria in PBS (Supplementary Table 5). Comprehensive consideration of the above factors, it resulted in a reduction of the conjugative transfer rate. In contrast, no remarkable effect on the rate of RP4 conjugation transfer was observed with the same concentrations of bulk alumina. It would appear that the effect of promoting conjugative transfer of nano-alumina exceeds the effects of mating temperature and mating time, although some reports have indicated that temperature and time may affect the conjugative transfer of drug resistance traits [41].

The effect of nano-alumina on the conjugative transfer of RP4 may be explained via the following potential mechanisms:

(1) It is known that oxidative stress (the SOS response) can damage cell membranes and may promote the horizontal transfer of antibiotic 

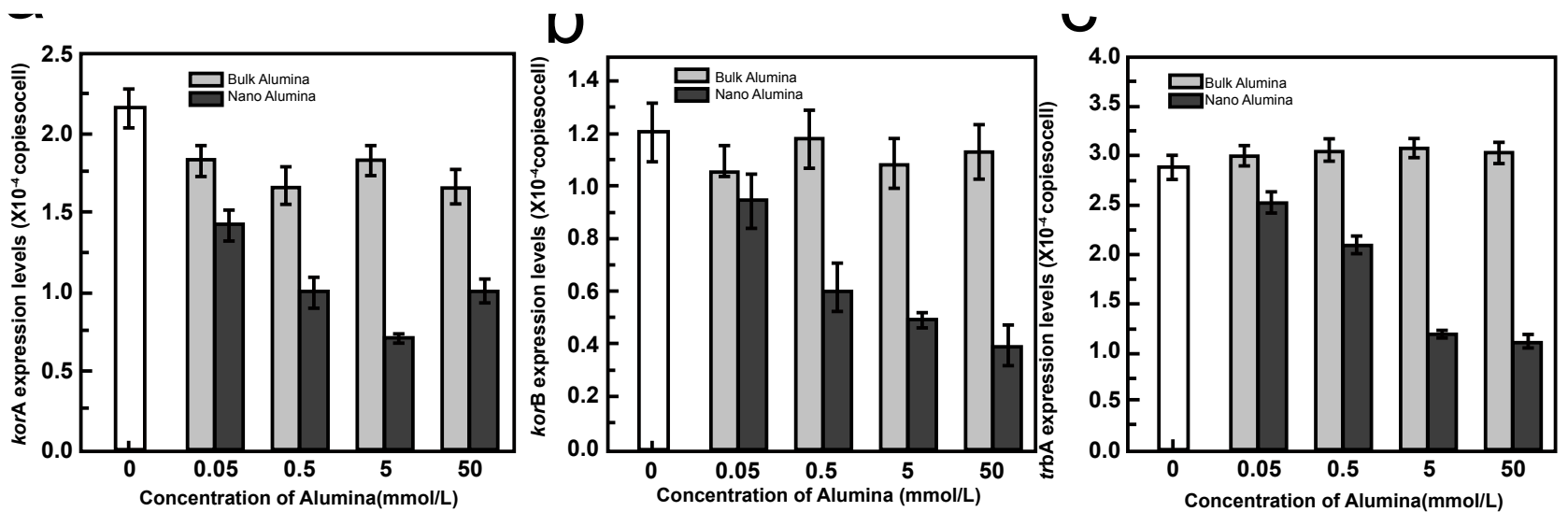

Figure 6: The mRNA expression of global regulation genes of RP4. The expression levels of korA (a), korB (b) and trbA (c) between bulk alumina groups and nano-alumina groups were significantly different (korA: $\mathrm{F}=1,769.68, \mathrm{P}<0.0001$; KorB: $\mathrm{F}=87, \mathrm{P}<0.05$; trbA: $\mathrm{F}=10046.8$, $\mathrm{P}<0.0001$ ); at different concentrations, the mRNA expression levels of the three genes were also significantly different $(k o r A: \mathrm{F}=181.23, \mathrm{P}<0.0001 ; k 0 r B: \mathrm{F}=102.4, \mathrm{P}<0.05 ;$ trbA: $\mathrm{F}=615.81, \mathrm{P}<0.0001)$. When conjugation was induced by bulk alumina, the three mRNA expression levels between pairwise comparisons of the different levels of treatment were not significant different $(P>0.05)$, but different concentrations of nano-alumina produced significant differences in the levels of three mRNA expression $(k o r A$ : $P<0.05$, except for 0.5 and $50 \mathrm{mmol} / \mathrm{L}[\mathrm{t}=-0.11034, \mathrm{P}=0.9132]$; korB: $\mathrm{P}<0.05$, except for 0.5 and $5 \mathrm{mmol} / \mathrm{L}[\mathrm{t}=0.008474, \mathrm{P}=0.9933], 0.5$ and $50 \mathrm{mmol} / \mathrm{L}[\mathrm{t}=0.1565, \mathrm{P}=$ 0.9877 ], 5 and $50 \mathrm{mmol} / \mathrm{L}$ [ $\mathrm{t}=0.00717, \mathrm{P}=0.9943$ ]; $\operatorname{trbA}: \mathrm{P}<0.05$, except for 5 and $50 \mathrm{mmol} / \mathrm{L}$ [t $=-0.7057, \mathrm{P}=0.4885]$ ).

resistance genes [42]. Nano-alumina increased the yield of $\mathrm{OH} \bullet$, which results in cell damage and attacks membranes directly [43]. Oxidative damage to membranes can arise through either damage to lipids or membrane proteins. It can cause the peroxidation of lipids both in vitro and in vivo [44]. When fatty acid chains become shortened or gain ionic charges, their ability to rotate within the membrane is altered and the membrane may become more fluid [45]. An increase in membrane fluidity results in a loss of structural integrity, which is required for the transport of most nutrients and DNA [46]. It has been found that the SOS response can promote the horizontal transfer of antibiotic resistance genes [42]. Our study showed that the conjugative transfer of RP4 increased with increasing concentrations of nano-alumina.

(2) Nano-alumina can enhance the conjugation efficiency through regulation the transcriptional activity of conjugative gene. The conjunctive transfer of RP4 can be divided into two processes. The first process is that the donor strain and recipient strain form conjugation bridges under the regulation of mating pair formation (Mpf) system gene trbBp. The second process is under the DNA transfer and replication (Dtr) system gene $\operatorname{trfA} p$ regulation, DNA is processed into a single chain, transferred from the donor to recipients and replicated from single chain to double chains in recipients. The conjugative transfer of IncP plasmids, such as broad-host-range plasmid RP4 and RK2, depends on the productions (protein) of the trfAp and trbBp genes, which had been certified by many researchers [36, 4751]. The transcriptional activities of the RP4 conjugation genes imply the amount of the productions (protein) of trfAp and trbBp genes. The transcriptional activity of $\operatorname{tr} b B p$ was enhanced after treatment with nano-alumina. It suggested that nano-alumina could promote expression of trbB protein which could interact with the first step of conjugative transfer, i.e. forming conjugation bridges. And this result was consistent with the results of TEM. In addition, nano-alumina could promote the transcriptional activity of trfAp. It presented that more trfA protein which could interact with the second step of conjugative transfer was produced under nano-alumina induced.

(3) Nano-alumina repressed the expression of global regulatory genes which coded the global repressors of RP4. The whole nucleotide sequence of RP4 has been compiled [38] and many studies have certified that there is a very complex regulatory circuit controlled by global repressors, KorA, KorB and TrbA, in the regulation of the plasmid genes for replication, transfer and stable inheritance [44, 4852]. As Kostelidou et al. and Pansegrau et al. [36,38] described that the presence of both KorA and KorB leaded to severely decrease the activity of promoter $\operatorname{trf} A p$, and the presence of both KorB and TrbA leaded to severely decrease the activity of promoter $\operatorname{tr} b B p$. Our results showed that the mRNA expression of $\operatorname{kor} A, \operatorname{kor} B$ and $\operatorname{trb} A$ were repressed by nano-alumina. It made the presence of KorA, KorB and TrbA decreased, as a result of the promoter trbBp and $\operatorname{tr} A p$ which were activated to promote the conjugative transfer of RP4.

Alumina plays an important role in the regulation of the composition of soil water, sediment water, and other natural water systems [57]. Nano-alumina, due to its huge surface area, has several applications as an adsorbent and a catalyst [16-19]. Nano-alumina has now become one of the two market leaders in the USA for nanosized materials [58]. The dosage of nano-alumina used in a previous research project was $34.2 \mathrm{~g} / \mathrm{kg}$ suspended solid [19], which was much higher than the concentration used in our present study. Kaegia et al. [20] found that the density of nanoparticles that were less than $20 \mathrm{~nm}$ in diameter in drinking water after conventional water treatment was between 7 and $10 \times 108$ particles $/ \mathrm{mL}$. We calculated the density of nanoalumina particles and found that the number of nano-alumina particles in our study was approximately $2.08 \times 106$ particles $/ \mathrm{mL}(0.5 \mathrm{mmol} / \mathrm{L})$, which significantly promoted the transfer of the RP4 plasmid. If nanomaterials are used in water treatment in the future, the residual amount of nanoparticles in drinking water may be even greater than this.

Once the nano-alumina and the bacteria that carry the plasmid encoding resistance traits meet within a water environment contaminated by pathogenic bacteria or opportunist pathogens, the horizontal transfer of drug-resistant plasmids among bacteria can be significantly promoted by nano-alumina. This function may be 
especially useful in waters with high localised bacterial concentrations, such as waste water and hospital sewage water.

\section{Conclusions}

In conclusion, we described the effect of nano-alumina on the horizontal transfer of antibiotic resistance genes by conjugation of the RP4 plasmid between bacteria. Nano-alumina was able to promote the horizontal transfer of multidrug-resistant genes by the conjugation of the RP4 plasmid. The transfer of drug-resistant genes may be explained by the actions of nano-alumina, which include the involvement of oxidative stresses, enhancing the transcription activities of conjugative genes, and repressing of the global regulatory factor genes for RP4 conjugation. The findings in this study support the notion that nanoalumina in the environment could result in ecological hazards. More important, an enhanced rate of plasmid transfer among microorganisms may have an enormous impact on human health and environmental safety.

\section{Acknowledgements}

This study was supported by the National Natural Science Foundation of China, No.30870453 and 81202163. We would like to thank Professor Julian E. Davies (Department of Microbiology and Immunology, Life Sciences Centre University of British Columbia in Canada) for the provision of the donor E. coli HB101 (RP4), Professor Stacic Erjavec (University of Ljubljana, Slovenia) who provided the pCB267 plasmid, and Professor Xingguo Wang (Hubei University, China) for the pCB182 plasmid. We would also like to thank Dr. Danfeng Yang, Jing Yin, and Zhuge Xi for providing several kinds of nanomaterials. We also wish to extend our thanks to Shu Wang, Jian Chen, Wu Yang, Aihua Huang, Lianyuan $\mathrm{Yu}$ for their assistance in the preparation of the experiments.

\section{References}

1. Heinemann JA, Ankenbauer RG, Amábile-Cuevas CF (2000) Do antibiotics maintain antibiotic resistance? Drug Discov Today 5:195-204

2. Ippolito G, Leone S, Lauria FN, Lauria E, Nicastri RP (2010) Methicillin-resistant Staphylococcus aureus: the superbug. Int J Infect Dis 14: S7-S11.

3. Kumarasamy KK, Toleman MA, Walsh TR, Bagaria J, Butt F, et al. (2010) Emergence of a new antibiotic resistance mechanism in India, Pakistan, and the UK: a molecular, biological, and epidemiological study. Lancet Infect Dis 10: $597-602$

4. Timothy RW, Janis W, David ML, Mark AT (2011) Dissemination of NDM-1 positive bacteria in the New Delhi environment and its implications for human health: an environmental point prevalence study. Lancet Infect Dis 11: 355-362.

5. Thomas CM, Nielsen KM (2005) Mechanisms of, and Barriers to, Horizontal Gene Transfer between Bacteria. Nature Reviews Microbiology, 3: 711-721.

6. Sota M, Top EM (2008) Horizontal gene transfer mediated by plasmids. In Lipps, G. (Ed.), Plasmids: Current Research and Future Trends ( Caister Academic Press, Norfolk, UK).

7. Welch TJ, Fricke WF, McDermott PF (2007) Multiple antimicrobial resistance in plague: an emerging public health risk. PLoS One 2: e309.

8. Heinemann JA (1999) How antibiotics cause antibiotic resistance.Drug Discov Today 4:72-79.

9. Johnsen AR, Kroer N (2007) Effects of stress and other environmental factors on horizontal plasmid transfer assessed by direct quantification of discrete transfer events. FEMS Microbiol Ecol 59: 718-728.

10. Maynard AD (2006) Nanotechnology: A Research Strategy for Addressing Risk. Woodrow Wilson International Center for Scholars, Washington, DC

11. Daughton CG Ternes TA (1999) Pharmaceuticals and personal care products in the environment: agents of subtle change? Environ Health Persp 107: 907938

12. Moore MN (2006) Do nanoparticles present ecotoxicological risks for the health of the aquatic environment? Environ Int 32: 967-976.

13. Ngomsik AF, Bee A, Draye M, Cote G, Cabuil V (2005) Magnetic nano and microparticles for metal removal and environmental applications: a review. C R Chim 8: 963-970
14. Uheida A, Iglesias M, Fontàs C (2006) Sorption of palladium (II), rhodium (III) and platinum (IV) on Fe3O4 nanoparticles. J Colloid Interface Sci 301: 402-408.

15. Li X, Elliott DW, ZhangW (2006) Zero-valent iron nanoparticles for abatement of environmental pollutants: materials and engineering aspects. Crit Rev Solid State Mater Sci 31:111-122.

16. Wiesner E (2006) Responsible development of nanotechnologies for water and wastewater treatment. Water Sci Technol 53:45-51.

17. Choi O, Yu CP, Esteban Fernández G, Hu Z (2010) Interactions of nanosilver with Escherichia coli cells in planktonic and biofilm cultures. Water Res 44 6095-6103.

18. Bhatnagar A, Kumar E, Sillanpaa M (2010) Nitrate removal from water by nanoalumina: Characterization and sorption studies. Chem Eng J 163: 317-323.

19. Wang ZS, Hung MT, Liu JC (2007) Sludge conditioning by using alumina nanoparticles and polyelectrolyte. Water Sci Technol 56: 125-132.

20. Kaegi R, Wagner T, Hetzer B, Sinnet B, Tzvetkov G, et al. (2008) Size, number and chemical composition of nanosized particles in drinking water determined by analytical microscopy and LIBD. Water Res 42:2778-2786.

21. Pronk W, Sinnet B, Meylan S, Boller M (2006) Characterization of nano- and microparticles in Swiss waters and their role in potable water production. Water Suppl 6: 21-29.

22. Adams LK, Lyon DY, Alvarez PJ (2006) Comparative eco-toxicity of nanoscale $\mathrm{TiO} 2, \mathrm{SiO} 2$, and $\mathrm{ZnO}$ water suspensions. Water Res 40: 3527-3532.

23. MacCormack TJ, Goss GG (2008) Identifying and predicting biological risks associated with manufactured nanoparticles in aquatic ecosystems. J Ind Ecol 12: $286-296$.

24. Lovrić J, Cho SJ, Winnik FM, Maysinger D (2005) Unmodified cadmium telluride quantum dots induce reactive oxygen species formation leading to multiple organelle damage and cell death. Chem Biol 12:1227-1234.

25. Zhu L, Chang DW, Dai L, Hong Y (2007) DNA damage induced by multiwalled carbon nanotubes in mouse embryonic stem cells. Nano Lett 7: 3592-3597.

26. Torney F, Trewyn BG, Lin VS, Wang K (2007) Mesoporous silica nanoparticles deliver DNA and chemicals into plants. Nat Nanotechnol 2: 295-300.

27. Yezhelyev MV, Qi L, O'Regan RM, Nie S, Gao X (2008) Proton-Sponge coated quantum dots for siRNA delivery and intracellular imaging. J Am Chem Soc 130: 9006-9012.

28. Abud-Archila M, Vazquez-Mandujano DG, Ruiz-Cabrera MA (2008) Optimization of osmotic dehydration of yam bean (Pachyrhizus erosus) using an orthogonal experimental design. J Food Eng 84: 413-419.

29. Escamilla EM, Dendooven L, Magana IP Parra R, De la Torre M (2000) Optimization of gibberellic acid production by immobilized Gibeberella fujikuro mycelium in fluidized bioreactors. J Biotechn 76: 147-155.

30. Fontani S, Niccolai A, Kapat A, Olivieri R. (2003) Studies on the maximization of recombinant Helicobacter pylori neutrophil-activating protein production in Escherichia coli: Application of Taguchi robust design and response surface methodology for process optimization. World J Microb Biot 19: 711-717.

31. Lee MT, Chen WC, Chou CC (1997) Medium improvement by orthogona array designs for cholesterol oxidase production by Rhodococcus equinum 23 . Process Biochem 32: 697-703.

32. Samuels AL, Lanka E Davies JE (2000) Conjugative junctions in RP4-mediated mating of Escherichia coli. J Bacteriol 182: 2709-2715.

33. Fox R, Zhong X, Krone SM, Top EM (2008) Spatial structure and nutrients promote invasion of IncP-1 plasmids in bacterial populations. ISME J 2:1024 1039

34. Zhong X, Krol JE, Top EM, Krone SM (2010) Accounting for mating pair formation in plasmid population dynamics. J Theor Biol 262:711-719.

35. Wang XG, Lin B, Kidder JM, Telford S, Hu LT (2002) Effects of environmental changes on expression of the oligopeptide permease (opp) genes of Borrelia burgdorferi. J Bacteriol 184: 6198-6206.

36. Kostelidou K, Jones AC, Thomas CM (1999) Conserved C-terminal region of global repressor KorA of broad-host-range plasmid RK2 is required for cooperativity between KorA and a second RK2 global regulator, KorB. J Biological Chem 289: 211-221.

37. Schneider K, Beck CF (1987) New expression vectors for identifying and 
Citation: Qiu Z, Yang D, Jin M, Hu L, Chen Z, et al. (2012) The Conjugative Transfer of the Multiresistance Gene Between Bacteria is Significantly Promoted by Nano-Alumina. J Nanomed Nanotechol 3:154. doi:10.4172/2157-7439.1000154

testing signal structures for initiation and termination of transcription. Method Enzymol 153: 452-461.

38. Pansegrau W, Lanka E, Barth PT, Figurski DH, Guiney DG, et al. (1994) Complete nucleotide sequence of Birmingham IncPa plasmids: compilation and comparative analysis. J Mol Biol 239: 623-663.

39. Geisenberger O, Ammendola A, Christensen BB, Molin S, Schleifer KH, et al (1999) Monitoring the conjugative transfer of plasmid RP4 in activated sludge and in situ identification of the transconjugants. FEMS. Microbiol Lett 174: 9-17.

40. Hotze EM, Phenrat T, Lowry GV (2010) Nanoparticle aggregation: challenges to understanding transport and reactivity in the environment. J Environ Qual 39: $1909-1924$.

41. Cullum J, Collins JF, Broda $P$ (1978) Factors affecting the kinetics of progeny formation with F'lac in Escherichia coli K12. Plasmid 1: 536-544.

42. Beaber JW, Kumar E, Sillanpaa M (2004) SOS response promotes horizontal dissemination of antibiotic resistance genes. Nature 427: 72-74

43. Cabiscol E, Tamarit J, Ros J (2000) Oxidative stress in bacteria and protein damage by reactive oxygen species. IntMicrobiol 3: 3-8.

44. Farr SB, Kogoma T (1991) Oxidative Stress Responses in Escherichia coli and Salmonella typhimurium. Microbiol Rev 55: 561-585.

45. McElhaney $R$ (1985) The effects of membrane lipids on permeability and transport in prokaryotes, pp 75-91. In G. Benga (ed.), Structure and properties of cell membranes. CRC Press, Inc., Boca Raton, Fla.

46. Dills SS, Apperson A, Schmidt MR, Saier MH (1990) Carbohydrate transport in bacteria. Microbiol Rev 44: 385-418.

47. Konieczny I, Doran KS, Helinski DR, Blasina (1997) A Role of TrfA and DnaA proteins in origin opening during initiation of DNA replication of the broad host range plasmid RK2. J Biol Chem 272: 20173-20178.

48. Zatyka M, Ggrazyna JB, Thomas CM (1997) Transcriptional and translational control of the genes for the mating pair formation apparatus of promiscuous IncP plasmids. J Bacteriol 179: 7201-7209.
49. Thorsted PB, Shah DS, Macartney D, Kostelidou K, Thomas CM (1996) Conservation of the genetic fwitch between replication and transfer genes of IncP plasmids but divergence of the replication functions which are major hostrange determinants. Plasmid 36: 95-111.

50. Theophilus BD, Cross MA, Smith CA, Thomas CM (1985) Regulation of the trfA and trfB promoters of broad host range plasmid RK2: identification of sequences essential for regulation by trfB/korA/korD. Nucleic Acids Res13: 8129-8142.

51. Schreiner HC, Bechhofer DH, Pohlman RF, Young C, Borden PA, et al. (1985) Replication control in promiscuous plasmid RK2: kil and kor functions affect expression of the essential replication gene trfA. J Bacteriol 63: 228-237.

52. Jagura-Burdzy G, Khanim F, Smith CA, Thomas CM (1992) Crosstalk between plasmid vegetative replication and conjugative transfer: repression of the trfA operon by trbA of broad-host-range plasmid RK2. Nucleic Acids Res 20: 39393944.

53. Jagura-Burdzy G, Thomas CM (1994) KorA protein of promiscuous plasmid RK2 controls a transcriptional switch between divergent operons for plasmid replication and conjugative transfer. P Nat Acad Sci USA 91: 10571-10575.

54. Jagura-Burdzy G, Thomas CM (1995) Purification of KorA protein from broad host range plasmid RK2: definition of a hierarchy of KorA operators. J Mol Bio 253: 39-50.

55. Motallebi-Veshareh M, Balzer D, Lanka E, Jagura-Burdzy G, Thomas CM (1992) Conjugative transfer functions of broad-host-range plasmid RK2 are correlated with vegetative replication. Mol Microbiol 6: 907-920.

56. Zatyka M, Jagura-Burdzy G, Thomas CM (1994) Regulation of transfer genes of promiscuous IncPa plasmid RK2: repression of Tra1 region transcription both by relaxosome proteins and by the Tra2 regulator TrbA. Microbiol 140 2981-2990.

57. Barbara KH, Hochhut B, Waldor MK (2004) Chemistry of alumina, reactions in aqueous solution and its application in water treatment. Adv Colloid Interface Sci 110: $19-48$

58. Abraham T (2000) Healthy prospects for nanoceramic powders. Ceram Inte 150: 28 